https://doi.org/10.22363/2312-8674-2019-18-3-710-713

Рецензия / Book Review

Гентшке В.Л., Сабенникова И.В., Ловцов А.С. Исследователи Русского зарубежья: биобиблиографический словарь = The researchers of Russian Diaspora: biobibliographical reference book. Москва; Берлин: Директ-Медиа, 2018. 396 с.

\author{
Д.г. Вайсман (рецензент) \\ Бруклинская публичная библиотека; г. Нью Йорк, 11229, США; \\ dvaisman@bklynlibrary.org
}

\title{
Gentshke, Valeria L., Sabennikova, Irina V., and Lovtsov, Alexander S. The researchers of Russian Diaspora: biobibliographical reference book. Moscow; Berlin: Direct-Media Publ., 2018, 396 p.
}

\author{
Demian G. Vaisman (reviewer) \\ Brooklyn Public Library; 2115, Ocean Av., Brooklyn, New York, 11229, USA; \\ dvaisman@bklynlibrary.org
}

At the end of 2018, the biobibliographical dictionary The Researchers of Russian Diaspora was published. This dictionary can be considered a unique result of study of the historical phenomenon of the Russian Diaspora as a whole and its most significant part - the Russian post-revolutionary emigration, which also celebrated a century of existence in 2018.

The book was prepared by a group of prominent scientific researchers and authors, supported by the fact that the dictionary was published as part of a series of books on the Russian Diaspora: Rossiyskaya emigratsiya (1917-1939): sravnitelno-tipologicheskoye issledovaniye [Russian Emigration (1917-1939): comparative typological study], ${ }_{1}^{1}$ Geografiya zarubezhnoy arkhivnoy Rossiki: annotirovannyy ukazatel publikatsiy iz otechestvennykh zhurnalov i prodolzhayushchikhsya izdaniy (2005-2010 gg.) [Geography of foreign archival Rossica: annotated index of publications from Russian journals and serial editions (2005 2010)], Zarubezhnaya arkhivnaya Rossika: geografiya razmeshcheniya, vyyavleniye, publikatsiya istochnikov [Foreign archival Rossica: geography of location, revealing, publica-

(C) Вайсман Д.Г., 2019

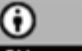

This work is licensed under a Creative Commons Attribution 4.0 International License https://creativecommons.org/licenses/by/4.0/

${ }^{1}$ I.V. Sabennikova, Rossiyskaya emigratsiya (1917-1939): sravnitelno-tipologicheskoye issledovaniye (Tver: Zolotaya bukva Publ., 2002).

${ }^{2}$ V.L. Gentshke, I.V. Sabennikova, and A.S. Lovtsov, Geografiya zarubezhnoy arkhivnoy Rossiki: annotirovannyy ukazatel publikatsiy iz otechestvennykh zhurnalov i prodolzhayushchikhsya izdaniy (20052010 gg.) (Moscow: Linor Publ., 2012). 
tion of sources], ${ }^{3}$ Arkhivnyye materiki Rossiyskogo zarubezhia: tendentsii i napravleniya izucheniya; annotirovannyy ukazatel [Archival continents of Russian Diaspora; trends and directions of research; Annotated index $],{ }^{4}$ Zarubezhnaya Rossiya: Organizatsii rossiyskoy emigratsii 1917-1939: materialy k mezharkhivnomu spravochniku [Russia Abroad: Organizations of Russian Diaspora 1917-1939: materials to inter-archive reference book]. ${ }^{5}$

The number of scientific publications and studies on the theme of Russia Abroad continues to grow. Numerous conferences and symposia on the most diverse range of questions are being conducted.

The purpose of the biobibliographical dictionary The Researchers of Russian Diaspora is to present to the scientific community the individuals who deal with the study of the history of the Russian Diaspora; to show the latitude of the scope of research problems and scientific directions; to present the geographical area of the Russian Diaspora as a whole and in different regions, and not less important, to present to the scientific community its contemporary researchers. And although the book is intended for specialists, it will certainly be noticed by the laymen, who are interested in the Russian Diaspora.

The circle of Russian researchers abroad who contributed to this biobibliographical dictionary is relatively wide. This is due to the fact that their determination of the concept of Russian Diaspora is not confined chronologically to the post-revolution emigration only; although, undoubtedly, the majority of contemporary Russian researchers are focused precisely on this period.

Russian diasporas of different historical periods differ considerably in their geography, number and in composition, with each period having its researchers; therefore, this approach taken by the compilers of the dictionary to the selection of authors is completely justified. Moreover, the most significant stages in the forming of the Russian Diaspora are the times of the dissolution of the Russian Empire in 1917 and later of the USSR in 1991, and also subsequent to this the processes of the forming of new states. It was then that, as a result of the re-drawing of borders, millions of compatriots ended up abroad, having considerably increased the numbers of the Russian Diaspora. Clearly, historically the members of the Russian Diaspora were not only ethnic Russians, but also representatives of other nationalities, who were of Russian (Soviet) origin and emigrated from Russia (the USSR). At present, the Russian Diaspora continues to exist. Therefore, the inclusion in the biobibliographical dictionary of researchers who are now studying all life cycles of Russian Diaspora, in our opinion, is justified.

In the first release of their publication, the compilers included data about 161 researchers of the Russian Diaspora. Among them there are many well-known scholars, who established themselves specifically in this area of study. In this analysis carried out by the authors of this project, it was found that almost half of the researchers in this area live in Moscow and Saint Petersburg. Approximately the same number of researchers are located in other regions of Russia. In this publication they are presented by researchers from Arkhangelsk, Vladivostok, Ekaterinburg, Ivanovo, Kazan, Kaliningrad,

\footnotetext{
${ }^{3}$ I.V. Sabennikova, and V.L. Gentshke, Zarubezhnaya arkhivnaya Rossika: geografiya razmeshcheniya, vyyavleniye, publikatsiya istochnikov (Moscow: Novyy khronograf Publ., 2014).

${ }^{4}$ I.V. Sabennikova, V.L. Gentshke, and A.S. Lovtsov, Arkhivnyye materiki Rossiyskogo zarubezhia: tendentsii i napravleniya izucheniya; annotirovannyy ukazatel (Moscow; Berlin: Direkt-Media Publ., 2015).

${ }^{5}$ I.V. Sabennikova, V.L. Gentshke, and A.S. Lovtsov, Zarubezhnaya Rossiya: Organizatsii rossiyskoy emigratsii 1917-1939: materialy k mezharkhivnomu spravochniku (Moscow; Berlin: Direkt-Media Publ., 2017).
} 
Krasnodar, Krasnoyarsk, Nizhniy Novgorod, Omsk, Petrozavodsk, to Rostov-on-Don, the Ryazan, Saransk, Surgut, Tver, Ul'yanovsk, Ufa, Khabarovsk, and Yaroslavl'.

The compilers of the dictionary included in this publication not only those researchers of the Russian Diaspora who still live in the territory of Russia, but also those who live outside of the Russian Federation. Among them are the descendants of the emigrants of the post-revolution wave and those who represent other waves of emigration, and also those whose teachers were emigrants from Russia. The countries in which the researchers of the Russian Diaspora reside, as a rule, either had or currently have Russian-language diasporas (Australia, Italy, the USA, Turkey and others), or Russian emigration has been a significant phenomenon in the history and culture of these countries (Bulgaria, Hungary, Greece, Serbia, the Czech Republic and others), or these states were once a part of the Russian Empire and the former USSR (Belorussia, Estonia and others). Another significant factor is the presence of archives, which contain documents on Russian emigration (Great Britain, the USA, France, Japan and others).

The list of researchers in the current publication is interesting. It shows that not only representatives of historical sciences (historians, the historiographers, archivists) are studying the problems of the Russian Diaspora, (they represent the majority, 53\%), but also philologists (about 15\%), and, to a somewhat smaller degree, experts in other branches of scientific knowledge such as architects, bibliographers, biologists, theologians, servicemen, geographers, geologists, engineers, physicists, and philosophers.

The dictionary is composed on the basis of information obtained from the researchers of the Russian Diaspora and augmented by information from reference and scientific literature.

The biobibliographical articles in the dictionary are sorted in alphabetical order. The information about the individuals included in this book is systematized to include an analysis of their activities, supplemented with a bibliographical section. Information about the dates of life, places of stay (in cases when a researcher spent a substantial part of his life in different countries, both countries are indicated), level of education, professional paths and scientific activity are included.

For foreign researchers, besides personal information in Russian (surname, name, patronymic, the name of the country of stay), similar information is provided in the language of the country of stay. In this publication the reader will be able to find information about many scientists and researchers whose ideological views were inaccessible in the Soviet period.

In addition, the dictionary presents the titles of dissertation studies, scientific publications, and projects that relate to the topic of the Russian Diaspora.

The fact that this biobibliographical dictionary is scientific is confirmed by the strict structure of the articles, and the presence of the scientific-reference apparatus which includes: an index of the main abbreviations; an index of abbreviations in the foreign languages; an index of the abbreviations of the names of periodicals, books and other publications; an index of names of organizations; an index of abbreviations and changes in the geographical names.

The articles of this dictionary not only make it possible to see the degree to which the problems of the Russian Diaspora have been studied, but also reveal 'gaps' in this area of study, which should contribute to further research of this broad topic.

Thus, it is possible to conclude that the compilers of the biobibliographical dictionary The Researchers of Russian Diaspora achieved their goal of developing a dic- 
tionary that provides a sufficiently complete and completely objective picture of study of the problems of the Russian Diaspora at the present stage.

In conclusion I would like to express a few comments to the authors of the dictionary. This publication should be continued. The current dictionary certainly does not include all researchers of the Russian Diaspora. Their numbers continue to grow due to constant interest in this problem, the expansion of thematic, chronological framework, and new archive data. Furthermore, it would be beneficial to design a data table that includes all the data obtained by the authors through their polling. This would produce a clearer collective picture of the researchers of the Russian Diaspora. This table could not only enhance this work, which is critical for historians, but also make it extremely useful.

Рукопись поступила: 29 января 2019 г.

Submitted: 29 January 2019

\section{Библиографический список}

Гентике В.Л., Сабенникова И.В., Ловцов А.С. География зарубежной архивной Россики: аннотированный указатель публикаций из отечественных журналов и продолжающихся изданий (2005-2010 гг.). М.: Линор, 2012. 87 с.

Сабенникова И.В. Российская эмиграция (1917-1939): сравнительно-типологическое исследование. Тверь: Золотая буква, 2002. 429 с.

Сабенникова И.В., Гентике В.Л. Зарубежная архивная Россика: география размещения, выявление, публикация источников. М.: Новый хронограф, 2014. 403 с.

Сабенникова И.В., Гентике В.Л., Ловиов А.С. Архивные материки Российского зарубежья: тенденции и направления изучения; аннотированный указатель. М.; Берлин: Директ-Медиа, 2015. 427 с.

Сабенникова И.В., Гентшке В.Л., Ловиов А.С. Зарубежная Россия: организации российской эмиграции 1917-1939: материалы к межархивному справочнику. М.; Берлин: Директ-Медиа, 2017. $407 \mathrm{c}$.

\section{References}

Gentshke, V.L., Sabennikova, I.V., and Lovtsov, A.S. Geografiya zarubezhnoy arkhivnoy Rossiki: annotirovannyy ukazatel publikatsiy iz otechestvennykh zhurnalov $i$ prodolzhayushchikhsya izdaniy (2005-2010 gg.). Moscow: Linor Publ., 2012 (in Russian).

Sabennikova, I.V. Rossiyskaya emigratsiya (1917-1939): sravnitelno-tipologicheskoye issledovaniye. Tver: Zolotaya bukva Publ., 2002 (in Russian).

Sabennikova, I.V., and Gentshke, V.L. Zarubezhnaya arkhivnaya Rossika: geografiya razmeshcheniya, vyyavleniye, publikatsiya istochnikov. Moscow: Novyy khronograf Publ., 2014 (in Russian).

Sabennikova, I.V., Gentshke, V.L., and Lovtsov, A.S. Arkhivnyye materiki Rossiyskogo zarubezhia: tendentsii i napravleniya izucheniya; annotirovannyy ukazatel. Moscow; Berlin: DirektMedia Publ., 2015 (in Russian).

Sabennikova, I.V., Gentshke, V.L., and Lovtsov, A.S. Zarubezhnaya Rossiya: Organizatsii rossiyskoy emigratsii 1917-1939: materialy k mezharkhivnomu spravochniku. Moscow; Berlin: DirektMedia Publ., 2017 (in Russian).

\section{Информация об авторе / Information about the author}

Вайсман Демьян Геннадиевич, доктор ис- Demian G. Vaisman, PhD. in History, Senior торических наук, старший библиотекарь Бру- Librarian of Brooklyn Public Library (USA).

клинской публичной библиотеки (США). 